IZA DP No. 4816

The Added Worker Effect and the Discouraged Worker Effect for Married Women in Australia

Xiaodong Gong

March 2010 


\title{
The Added Worker Effect and the Discouraged Worker Effect for Married Women in Australia
}

\author{
Xiaodong Gong \\ Australian Treasury \\ and IZA
}

\author{
Discussion Paper No. 4816 \\ March 2010
}

IZA

P.O. Box 7240

53072 Bonn

Germany

Phone: +49-228-3894-0

Fax: +49-228-3894-180

E-mail: iza@iza.org

\begin{abstract}
Any opinions expressed here are those of the author(s) and not those of IZA. Research published in this series may include views on policy, but the institute itself takes no institutional policy positions.

The Institute for the Study of Labor (IZA) in Bonn is a local and virtual international research center and a place of communication between science, politics and business. IZA is an independent nonprofit organization supported by Deutsche Post Foundation. The center is associated with the University of Bonn and offers a stimulating research environment through its international network, workshops and conferences, data service, project support, research visits and doctoral program. IZA engages in (i) original and internationally competitive research in all fields of labor economics, (ii) development of policy concepts, and (iii) dissemination of research results and concepts to the interested public.
\end{abstract}

IZA Discussion Papers often represent preliminary work and are circulated to encourage discussion. Citation of such a paper should account for its provisional character. A revised version may be available directly from the author. 


\section{ABSTRACT}

\section{The Added Worker Effect and the Discouraged Worker Effect for Married Women in Australia*}

This paper investigates both the added worker effect (the labour supply responses of women to their partners' job losses) and the discouraged worker effect (workers withdrawing from the labour market because of failed searches) for married women in Australia, with the emphasis on the former. We focus on the partners' involuntary job loss experiences, and analyse women's labour market activities in the periods before and after their partners' job loss. By estimating fixed effects labour supply equations using the first seven waves of data from the HILDA Survey, we find a significant added worker effect in terms of increased full time employment and working hours. The findings also suggest that it is harder for the female partners of males who have recently lost jobs to enter the labour market than for those already working to increase their working hours to compensate for lost income incurred by their partners' job loss. We also find the effect to be persistent in that, one year after the partners' job loss, more of those women would still like to work longer hours than they actually were. By investigating the relationship between self-assessed job-finding probability on job-seekers' subsequent labour force participation, and by studying the relationship between labour force participation of all married women and the regional unemployment rate, we also find a substantial discouraged worker effect.

JEL Classification: $\quad \mathrm{C} 23, \mathrm{~J} 20, \mathrm{~J} 60$

Keywords: $\quad$ added worker effect, discouraged worker effect, panel data

Corresponding author:

Xiaodong Gong

The Treasury

Treasury Building

Langton Crescent

Parkes, ACT 2600

Australia

E-mail: xiaodong.gong@treasury.gov.au

\footnotetext{
* This working paper was originally published by the Australian Treasury as Treasury Working Paper No. 2010-01. The views expressed are those of the author, and not necessarily those of the Australian Treasury. I thank Bruce Bradbury, Robert Breunig, Owen Freestone, Bob Gregory, Guyonne Kalb, Michael Kouparitsas, Laura Llewellyn, lyanoosh Reporter, Matthew Toohey, Leo Vance, participants at the 2009 HILDA Survey Research Conference and at the seminar in NATSEM, and colleagues from the Modelling and Behavioural Analysis Unit at the Treasury for their useful comments and suggestions. Special thanks go to Anthony King, who assisted me in revising the paper. This paper uses unit record data from the Household, Income and Labour Dynamics in Australia (HILDA) Survey. The HILDA Project was initiated and is funded by the Australian Government Department of Families, Housing, Community Services and Indigenous Affairs (FaHCSIA) and is managed by the Melbourne Institute of Applied Economic and Social Research (Melbourne Institute). The findings and views reported in this paper, however, are those of the author and should not be attributed to either FaHCSIA or the Melbourne Institute.
} 


\section{Introduction}

The effect on employment is a clear dimension of the economic downturn that followed the global financial crisis from 2008 - for example, the Australian unemployment rate (seasonally adjusted) started rising sharply from 4.3 per cent in September 2008. The overall labour market impact is, however, likely to be more than just the direct job losses stemming from weak demand conditions. In addition to the direct income and human capital loss from an individual's job loss, any family members will also suffer from the adverse income shocks and may respond to these, with further implications for the labour market. The extent to which those responses materialise depends upon the market conditions. Thus, to evaluate the full-scale impact of rising or high unemployment, it is important to take into account its repercussion effects. Do members of couples respond to their partners' job loss by increasing their own labour supply and, if so, what is the magnitude? Also, what are the implications of weak labour market conditions on individuals' labour market attachment in the short and long run? The answers to these questions are key parts to understanding the full impact of job loss on households.

Economic models of family utility maximisation predict that, to compensate the income losses due to their partners' job loss, individuals may choose to increase their own labour supply, or become 'added workers'. This labour supply response is a transitory way of smoothing inter-temporal income and consumption for a family, and is often called the 'Added Worker Effect' (AddWE). In the context of a dynamic family labour supply model, the added worker effect may also be affected by employment uncertainty and households' liquidity constraints (see more theoretical discussions in, for example, Mincer 1962, 1966; Ashenfelter 1980; Killingsworth and Heckman 1986; Rosen 1992; Lundberg 1985). The issue has been of interest to economists and policy-makers concerned with the labour force participation of married women over the business cycle. In the short run, the AddWE may put more supply pressure on an already stressed labour market in an economic downturn if most of these added workers can not find jobs. Still, more people developing or retaining an attachment to the labour market is likely to be positive in the long term. 
In addition to the AddWE, a 'discouraged worker effect' (DWE) is also predicted by economic theories and often empirically confirmed. The DWE hypothesises that, after failed job searches or when facing a gloomy prospect of finding jobs, individuals may give up looking for jobs and withdraw from the labour market altogether. The DWE thus works in the opposite direction to the AddWE.

This paper investigates the AddWE and the DWE for married women ${ }^{1}$ in Australia using panel data drawn from the seven waves of the longitudinal Household, Income and Labour Dynamics in Australia (HILDA) Survey. The AddWE is tested using a framework suggested by life-cycle labour supply models and fixed effects panel data techniques which identify the immediate and persistent effects of the male partner's job loss on women's labour supply. The robustness of the model specification is checked with a random panel data model and OLS.

The focus of the AddWE analysis is on the labour supply behaviour of married women with partners experiencing recent job losses. The effects on labour supply are measured by changes in the likelihood of labour force participation and full time employment, and also by changes in the likelihood of working longer hours and of preferring to work more hours. To our knowledge, similar analysis has not previously been done for Australia.

To get a more comprehensive assessment of the effects of rising or high unemployment on the labour supply of married women, the DWE is investigated by analysing the impact of the unemployment rate on all married women's participation. It is also studied by evaluating the impact of the self-assessed job-finding probability on the subsequent labour force participation of job-seekers.

The rest of the paper is arranged as follows. Section 2 surveys the literature, with the data described in Section 3. The methodology and empirical findings of the AddWE analysis are presented in Section 4, with the discouraged worker effect analysed in Section 5. Conclusions are drawn out in Section 6.

\footnotetext{
${ }^{1}$ Throughout the paper, the term 'married women' refers to all legally married and cohabitated women. They are also referred as 'the wives', and their partners are referred to as 'the partners' or 'the husbands'.
} 


\section{Literature}

The literature studying the added worker effect can be dated back to as early as the 1940s (Woytinsky, 1940). Despite the effect being unambiguously predicted by the theoretical models, empirical work has yet to reach a consensus regarding its magnitude, or even its existence. While some early studies did discover some small but significant added worker effect (for example, Mincer 1962; Bowen and Finegan 1968; Heckman and MaCurdy 1982; Lundberg 1985; Gruber and Cullen 1996; and Spletzer 1997), some other studies of that period failed to find any such effect (for example, Layard, Barton, and Zabalza 1980; Pencavel 1982; and Maloney 1987, 1991).

Stephens (2002) argues that the results of early international studies may not be readily applicable to an understanding of the added worker effect due to a host of methodological issues. First of all, these studies focused upon the labour force participation of individuals with unemployed partners and did not distinguish between partners who experienced recent job losses and those who were observed to be unemployed. This is important because not all unemployed individuals experienced recent job losses or unexpected income reductions. Some of the unemployment may be long term or have been anticipated by families. As stressed by Lundberg (1985), such anticipated unemployment would not induce an AddWE unless the families faced credit constraints. Furthermore, individuals with long-term unemployed partners may well be likely to have similarly low labour supply patterns as their partners due to assortative matching in marriage. Thus, where these earlier studies of the AddWE focused on simple labour force status, rather than on the dynamics around job loss, a substantial portion of job losers could be excluded from the 'treatment group' and the inclusion of the long-term unemployed in the 'treatment group' may disguise the AddWE. An indication of the magnitude of this issue comes from the HILDA data used in this analysis, where only about $32 \%$ of the married men who reported losing jobs in the previous twelve months were not employed at the time of the interview.

A second issue is that, after a partner loses his job, it may take some time or even be impossible for the female partner to adjust her labour supply behaviour. Thus, the effect may take time to materialise and be difficult to be identified; at least in the short run. 
Indeed, when Stephens (2002), using the Panel Study of Income Dynamics (PSID), singled out those workers who had experienced job loss and addressed the long-term effects, he did find a small but significant and persistent added worker effect for the United States. He found that the effect could last as long as five years. Some other recent studies, such as Morisserre and Ostrovsky (2008) for Canada, have used similar approaches to Stephens (2002) and obtained consistent findings.

Finally, the labour supply response may be in the form of increased hours worked for existing workers. As such, measurement of the effect solely in terms of employment rates may just be the lower bound of the true effects.

Australian studies have examined the AddWE using approaches that differ from those used in the majority of the international literature. For example, Bradbury (1995) studied the patterns of unemployment for married men and women using data drawn from 1991 Labour Force Survey conducted by Australian Bureau of Statistics (ABS) and administrative data from the then Department of Social Security. He argued that the employment gap between women with unemployed partners and women with employed partners was mainly due to the differences in individual characteristics of the two groups of women. The AddWE was seen to coexist with the DWE but the net effects contributed only a little to the observed differences in employment patterns. Bradbury did not distinguish between unemployment and job loss, and no formal econometric analysis was conducted in the paper.

Similarly, Lenten (2000) attempted to identify the AddWE using Australian data by investigating the relationship between the time series of aggregate labour force participation rates of partnered individuals and unemployment rates. Lenten found that, the higher the unemployment rate, the lower was the rate of labour force participation, and concluded that there was no AddWE but there was a DWE. These data do not, however, provide a reasonable basis for any conclusions about the AddWE, as the population of individuals with partners who have experienced a recent job loss is only a small subset of the total population of partnered individuals. The observed negative relationship between the participation rate of married people and the unemployment rate 
is a likely result of multiple effects, including both the AddWE and the DWE, and these two effects can not be distinguished using these time series data for aggregate populations.

\section{Data and initial analysis}

The data used for the analysis are drawn from the first seven waves of the longitudinal HILDA Survey (covering the period from 2001 to 2007). The survey has a sample of around 8,000 households and collects extensive information on individuals' current labour market status, working hours, labour market history, income and earnings, and demographic characteristics of both households and individuals. We focus upon married women (both legally married and cohabitating) in couples where, in all waves, both partners were aged between 22 and 59 years and neither partner reported being unable to work due to a long term health condition. The resulting sample consists of 18,448 observations with about 2,500 to 3,000 married women in each wave.

Summary statistics of the sample are presented in Table A of the Appendix. From the table, we can see that, on average, around 72 per cent of women were employed (of which, around half were working full-time), about 2 per cent of the women were unemployed and the remaining 26 per cent were not participating in the labour force. Among the male partners, on average over the waves, 91 per cent were employed and 2 per cent were unemployed. As would be expected with this restricted sample, both the participation and employment rates for this group are higher than the Australian average over the same period.

As discussed above, the static labour force status of the partner is not appropriate for identifying the added worker effect. Not all unemployed workers have recently lost jobs, and not all those workers who have recently lost jobs are observed as unemployed. Rather, the key variables used to identify the population in scope for an added worker effect are the variables indicating the recent job loss experiences of the male partners. In the survey, each individual is asked whether he/she lost or changed jobs during the last 12 months and, if so, the reasons. From these questions, we construct the job loss variables at various time points, for example, whether the partner experienced job loss in the 12 
months preceding the interview (referred to as the 'current period'), in the period of 12 to 24 months before the interview (referred to as the 'previous period'), and in the 12 months after the interview (referred to as the 'future period'). For the purposes of this analysis, a male partner is regarded as having experienced involuntary job loss if he lost or changed jobs for one of the following reasons: 'got laid off', 'no work available', 'retrenched', 'made redundant' or 'employer went out of business' in the case of employees; or 'self employed business closed down for economic reasons' in the case of the self-employed. On average, about 3.1 per cent of the male partners had experienced job loss over the year preceding the interview, and another 2.2 per cent experienced job loss between 24 and 12 months before the interview.

To illustrate the difference between a direct measure of the male partner's recent job loss, and the status of unemployment as its proxy, the two variables are cross-tabulated in Table 1. It is obvious from the table that the majority of the male partners who had lost jobs over the previous 12 months were observed working at the time of interview; only around a sixth of them were observed to be unemployed. This is a likely outcome of the favourable economic environment which enabled those who lost jobs to find new jobs quickly. Meanwhile, most (about three-quarters) of those male partners who were observed as unemployed had not lost jobs in the preceding 12 months.

Table 1. Male partners’ labour force status vs. recent job loss experiences (\%)

\begin{tabular}{ccccc}
\hline \hline & & \multicolumn{2}{c}{ Labour force status } & Total \\
Job loss in the current period & Employed & Unemployed & Non-participation & 96.9 \\
No & 88.3 & 1.7 & 6.9 & 0.4 \\
Yes & 2.2 & 0.5 & 7.3 & 1 \\
Total & 90.5 & 2.2 & 100 \\
\hline \hline
\end{tabular}

Source: Author's calculation using HILDA waves 1 -7, see text.

The measures of the female partners' labour market activity that are used in the analysis are: labour force participation rate, full-time employment rate, the rate of increase in hours worked (from the previous wave), and the percentage who would prefer to work more hours. As discussed earlier, use of the labour force participation rate alone can only capture any labour supply effect in terms of movements in and out of the labour market, with any changing hours by the existing workers being ignored. This is addressed here through the addition of the measures covering full-time employment and increase in 
hours worked. Including the preference to work more hours enables us to analyse the potential rather than just the realised added worker effect.

The implications of using the male partner's recent job loss experience, rather than labour force status, in an analysis of the AddWE can also be explored by comparing the association of the measures of female partners' labour market activity with the two alternative indicators of the male partners' experience. This is done in Figures 1 and 2 where we present the female partners' labour market activity against the employment status of the male partners (Figure 1) and against their job loss status (Figure 2).

\section{Figure 1. Females' labour market activities by partners' employment status}

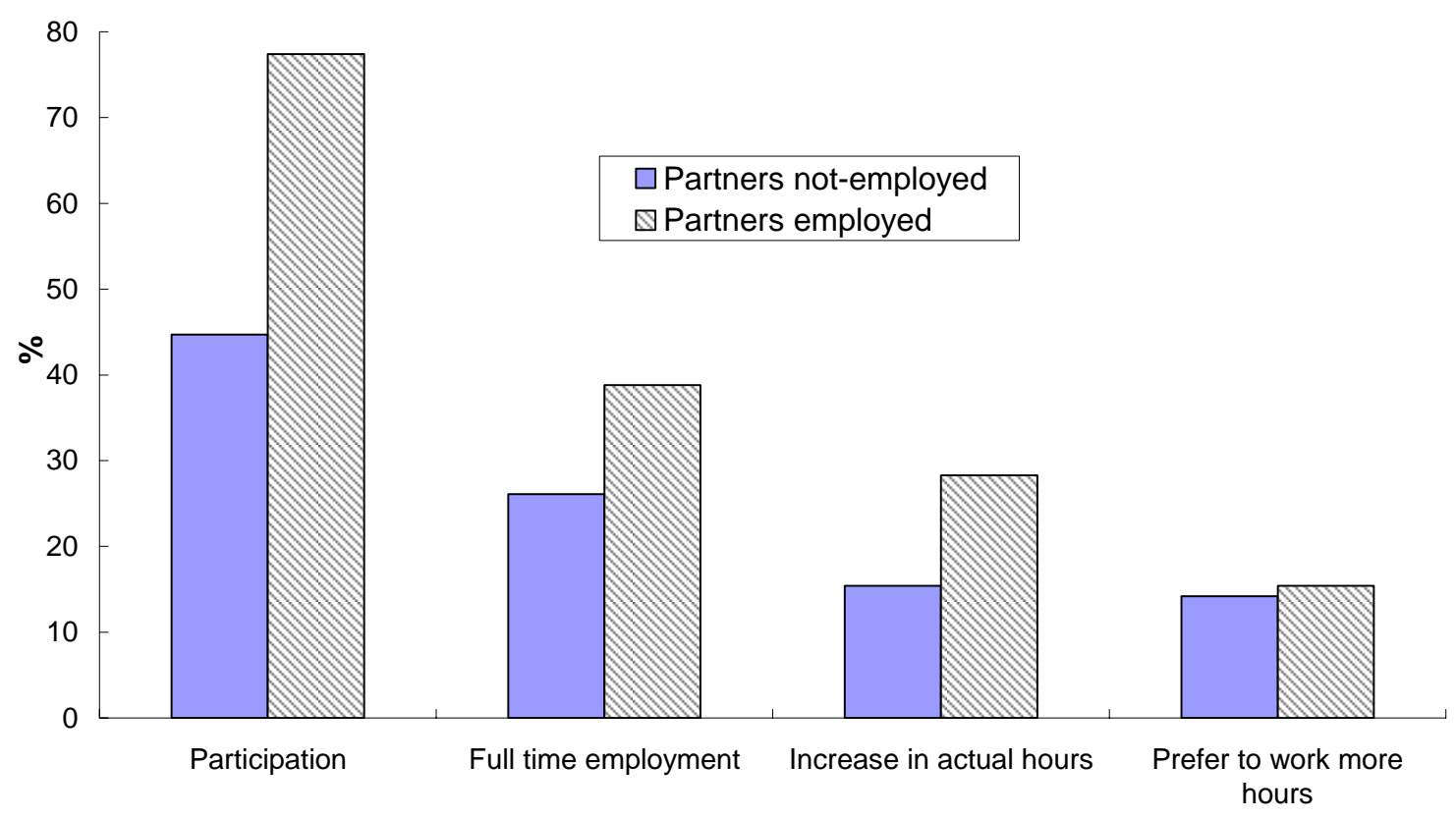

Labour market activities of married women

Source: Authors' calculation using HILDA, waves 1-7, see text.

From Figure 1, it is clear that, by all four measures, the labour market activities of women with employed partners are stronger than that of their counterparts with notworking partners. The labour force participation rate of the former group was about 32 percentage points higher than the latter, the percentage of women working full time was about 13 percentage points higher, the percentage of women working more hours since the previous wave is about 13 percentage points higher, and the percentage preferring to increase their hours is slightly higher. Thus, a study using employment status of the male 
partner would not be expected to find any added worker effect: if anything, it would be likely to find the opposite effect.

Figure 2 is a similar chart except that the distinction now is along the lines of the male partners' recent job loss (where job loss occurred in the previous 12 months). It reveals a completely different pattern. The proportions of women who participated or worked more hours across waves are roughly the same for those females with partners who experienced a recent job loss across waves and those whose partners did not, but about six percentage points more of the first group worked full time and five percentage points more preferred to work more hours if they could. The patterns suggest that women may move into full-time jobs when their partners experience a recent job loss, rather than entering the labour market from non-participation, and that some women are unable to increase working hours as much as they would like to. When the measure of partners' job loss was extended to also include those who had lost jobs in the period from 24 to 12 months preceding the interview, similar patterns held. ${ }^{2}$

\footnotetext{
${ }^{2}$ Of married women with a partner experiencing job losses during the two years leading to the interview, about 72 per cent participated in the labour force, 41 percent worked full time, 28 per cent increased hours worked, and 20 percent preferred to increase their hours worked. At the same time, of married women with a partner not experiencing job losses during the two years leading to the interview, about 74 per cent participated in the labour force, 37 percent worked full time, 27 per cent increased hours worked, and 15 percent preferred to increase their hours worked.
} 
Figure 2. Females' labour market activities by partners' recent job loss experiences

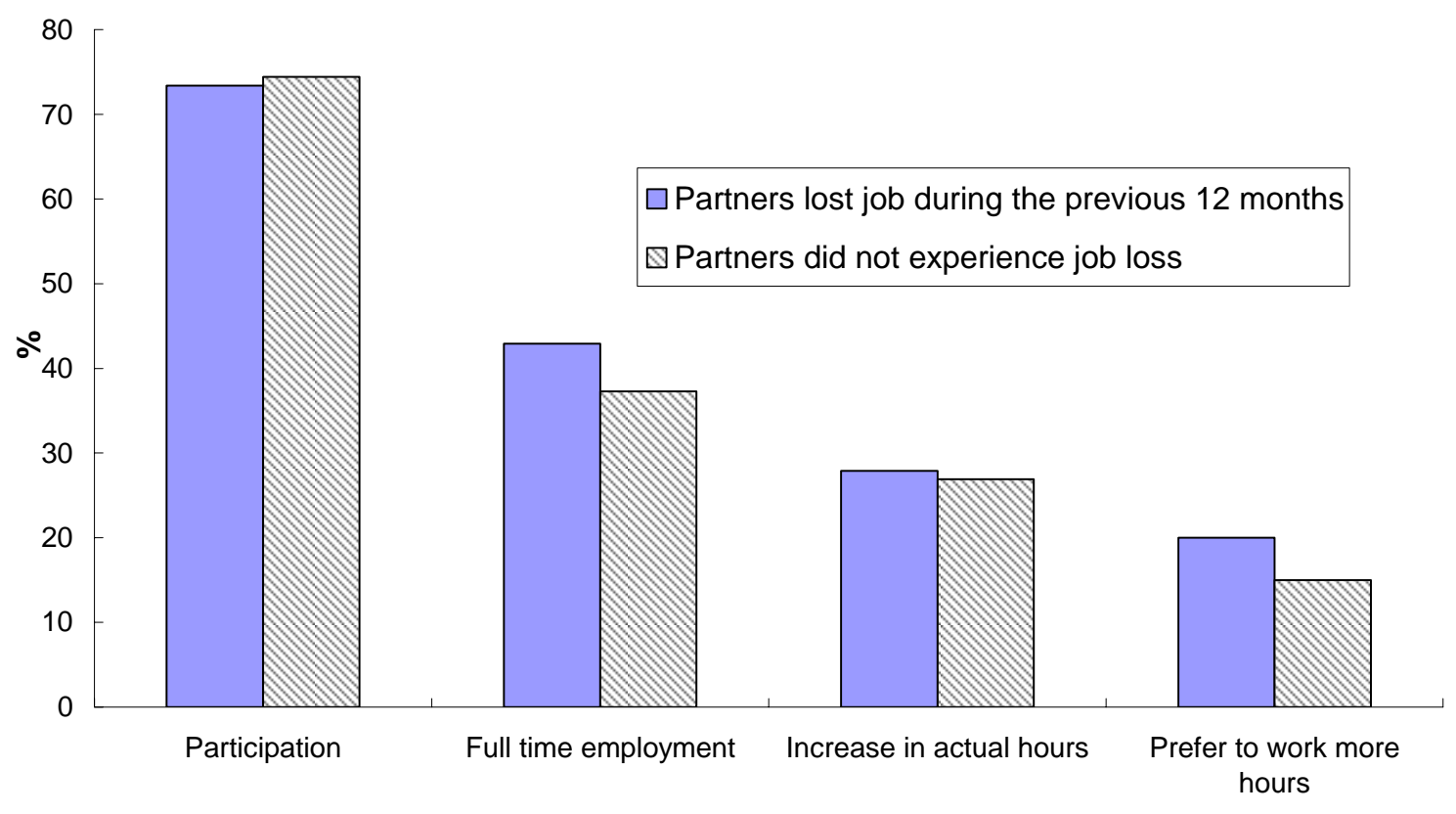

Labour market activities of married women

Source: Authors' calculation using HILDA, waves 1-7, see text.

A first indication of the existence of a discouraged worker effect (DWE) can be obtained by examining the relationship between the labour force participation and unemployment rates - where there is a DWE, a negative relationship would be expected. One way to examine this relationship is by comparing participation rates in geographic areas which have high and low unemployment rates. Over the sample period, when the economy was generally booming, the average unemployment rate across the eight Australian states and territories was about 5.5 per cent. The average participation rate of women in the states with the unemployment rate above that level was 72 per cent, which was 5 percentage points lower than in the other states (77 per cent). This suggests the existence of a DWE, which can also be examined through analysing the subsequent labour supply behaviour of women who searched for jobs.

In the HILDA Survey, unemployed individuals are asked to assess the probability of finding a job in the following 12 months. From the first to the sixth wave (when women's subsequent labour supply could be observed), 396 married women were searching for jobs and provided answers to this question. For this group of women, Table 2 compares the self-assessed probability of finding a job with the actual outcome 12 months later. On 
average, these women predicted their chances of finding a job in a year to be 64 per cent, and 65 per cent of these women were in fact participating in the labour force a year later (that is, 35 per cent had withdrawn from the labour force). Allowing for the points that participation is not the same as employment, and that some women may have found and then lost jobs over the period, the self-assessed probability of finding a job does seem to be a reasonable indicator of the actual probability. If the discouraged worker effect is operating, those women with lower self-assessed job-finding probabilities would be expected to have a higher rate of withdrawal from the labour market than their counterparts with higher self-assessed job-finding probabilities. The data show that this is indeed the case - a 76 per cent subsequent participation rate for women with a self-assessed probability of finding a job of more than 50 per cent compares with just a 51 per cent subsequent participation rate for those women whose self-assessed probability of finding a job was less than 50 per cent.

Table 2. Self-assessed job finding probability and labour force participation of married women looking for a job

\begin{tabular}{ccc}
\hline \hline Prob. of getting a job in a year & Participation a year later & \multicolumn{2}{c}{ Avg. prob. of finding a job in a } \\
& & year \\
$>50 \%$ & $76 \%$ & $87 \%$ \\
$\leq 50 \%$ & $51 \%$ & $33 \%$ \\
Total & $65 \%$ & $64 \%$ \\
\hline \hline
\end{tabular}

Source: Authors' calculation using HILDA, waves 1-7, see text.

\section{The added worker effect}

\section{Theoretical background of the added worker effect}

We take a similar approach as Stephens (2002), which is based upon a family life-cycle labour supply model with uncertainty, and is an extension of the single worker model used by MaCurdy (1985). According to the model, at any point in time, the household is assumed to maximise utility from both partners' leisure and the total household consumption over the rest of its lifetime with the expected utility updated with any new information available since the previous period. In each period, the female partner's labour supply depends on both partners' wages and the marginal utility of wealth that is determined by the expected values of the future variables (including the wage offers for both partners) and the evolution in their distributions. Both past experience, such as job losses, and any change in beliefs about future prospects, such as the probabilities of 
losing and finding jobs, will affect those expectations and the evolution in the distributions and thus enter the female partner's labour supply function.

The model implies that the added worker effect operates through two channels. The main channel is through the reduction in the expected lifetime wealth due to the male partner's job loss. The loss in lifetime wealth increases the marginal utility of wealth in all periods so the individual is likely to work more in every future period to compensate. The other channel is through the cross-wage effect between partners. ${ }^{3}$ As discussed by Stephens (2002), the direction of the job-loss effect through this channel is unclear because it depends upon whether the couples' leisure times are substitutes or complements. Nevertheless, this effect is believed to be small and secondary and of short term. Most of the empirical literature finds that the cross-wage effect is indeed very small.

The magnitude of the added worker effect depends upon the size of the permanent wealth loss. The larger the wealth loss, the larger the effect is. In addition, it will also depend in this model on how sudden the job loss is. If the partner's job loss comes as a shock to the family, the woman will then increase her labour supply accordingly. If, on the other hand, it is well anticipated, the female partner may have adjusted to it long before the job loss occurs and, at that point, may only change her labour supply slightly if at all. See MaCurdy (1985) and Stephens (2002) for formal presentation and more detailed discussion of the model.

\section{Empirical Specification}

The life-cycle labour supply model discussed above implies that a woman's labour supply $\left(H_{i t}\right)$ in family $i$ at time $t$ is in general a function of the family's marginal utility of wealth $\left(\lambda_{i t}\right)$, parameters reflecting the marginal utility of her leisure time $\left(\omega_{i}\right)$, her wage offer ( $\left.\ln w_{i t}^{f}\right)$, and 'taste modifiers' of the female's leisure $\left(x_{i t}\right)^{4}$ :

\footnotetext{
${ }^{3}$ The cross-wage effect is the effect of one partner's wage on the labour supply of the other partner in the couple.

${ }^{4}$ Stephens (2002) derives an empirical equation by specifying an inter-temporal utility function which assumes inter-temporal separability between partners' leisure times in addition to those assumptions in the standard life-cycle labour supply models.
} 


$$
H_{i t}=g\left(\lambda_{i t}, \omega_{i}, \ln w_{i t}^{f}, x_{i t}\right) .
$$

Using similar reasoning as MaCurdy (1985), suppose $\lambda_{i t}$ is a function of the initial marginal utility of wealth and the subsequent forecast errors which are functions of job losses, then the probabilities of labour force participation $\operatorname{Pr}^{p}$ and full time employment $\operatorname{Pr}^{f}$, which are all functions of the arguments in Equation (1), can be specified as follows, $\operatorname{Pr}^{m}{ }_{i t}=P\left(\alpha_{i 0}+\sum_{s=-1}^{1} \eta_{s} D_{i t}^{s}+\gamma \ln w_{i t}+\beta x_{i t}\right)$, where $m=p, f$

where $\alpha_{i 0}$ is a household specific effect reflecting the initial marginal utility of wealth, the marginal utility of the female's leisure time, and so on. $D_{i t}$ 's are mutually exclusive dummy variables indicating partners' job loss experiences, with $D_{i t}^{0}=1$ for job loss in the current period; $D_{i t}^{-1}=1$ for job loss in the previous but not the current period; and $D_{i t}^{1}=1$ for job loss in the future period only. ${ }^{5}$ Thus those who experienced job loss in the current period as well as in the past and/or in the future are also included in $D_{i t}^{0}$, so that its coefficient indicates the cumulative effect. The reference group is those females with partners who did not experience job loss in any of the three periods. The relationship between these variables and job loss events are described in Table 3. For example, someone who lost a job in the current period and also lost a job in the next period would have $D_{i t}^{-1}=0, D_{i t}^{0}=1$, and $D_{i t}^{1}=0$. This definition does make the number of observations with $D_{i t}^{-1}=1$ and/or $D_{i t}^{1}=1$ smaller than if the variables were defined solely with reference to single periods. This may also partly explain the low significance of their coefficients (see the next section). Because of the relatively short panel we have, we are not able to take into account the longer term effects as in Stephens (2002). The added worker effects are captured by $\eta_{s}$, the coefficients of these dummies. The $\eta_{-1}$ coefficient refers to the effect of the partner's job loss in the previous period and part of the future

\footnotetext{
${ }^{5}$ The way these variables are defined is to make them mutually exclusive and the interpretation of these coefficients as meaningful as possible. Defining these variables to be indicators of job loss in each period without making them mutually exclusive (such as in Stephens, 2002) makes it more difficult to interpret the parameters, because the reference group for each of the dummies changes so the meaning of the coefficients also changes and the coefficients cannot be explained as the differences with the designated reference group - those who did not have a job loss in the previous, the current, or the future period.
} 
job loss effect; $\eta_{0}$ refers to the cumulative added worker effects as long as the partners lost jobs in the current period; and $\eta_{1}$ refers to the pure future job loss effect.

Table 3. Relationship between the job loss variables and job loss events

\begin{tabular}{|c|c|c|c|}
\hline \multicolumn{3}{|c|}{ 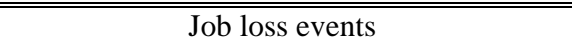 } & \multirow[b]{2}{*}{ Job loss variables } \\
\hline $\begin{array}{l}\text { Previous } \\
\text { period }\end{array}$ & $\begin{array}{l}\text { Current } \\
\text { period }\end{array}$ & Future period & \\
\hline 1 & 1 & 1 & $D_{i t}^{-1}=0, D_{i t}^{0}=1, D_{i t}^{1}=0$ \\
\hline 1 & 1 & 0 & $D_{i t}^{-1}=0, D_{i t}^{0}=1, D_{i t}^{1}=0$ \\
\hline 0 & 1 & 0 & $D_{i t}^{-1}=0, D_{i t}^{0}=1, D_{i t}^{1}=0$ \\
\hline 0 & 1 & 1 & $D_{i t}^{-1}=0, D_{i t}^{0}=1, D_{i t}^{1}=0$ \\
\hline 1 & 0 & 1 & $D_{i t}^{-1}=1, D_{i t}^{0}=0, D_{i t}^{1}=0$ \\
\hline 1 & 0 & 0 & $D_{i t}^{-1}=1, D_{i t}^{0}=0, D_{i t}^{1}=0$ \\
\hline 0 & 0 & 1 & $D_{i t}^{-1}=0, D_{i t}^{0}=0, D_{i t}^{1}=1$ \\
\hline 0 & 0 & 0 & $D_{i t}^{-1}=D_{i t}^{0}=D_{i t}^{1}=0$ \\
\hline
\end{tabular}

The ability for individuals to vary their labour supply is often constrained at least in the short run. The coefficients may also reflect these constraints. When the functional form of $P$ is specified as linear, Equation (2) becomes a linear probability model, and can be estimated by the usual linear fixed or random effects techniques. However, random effects models may be inconsistent because the time-invariant household effect reflects the initial assets, the interest rate, and wages in all periods which are all correlated with the other explanatory variables. When the time-invariant household effect is specified as normal, the model becomes a panel data probit model. Our baseline estimates are obtained using a standard linear fixed effects estimator, which is asymptotically consistent.

Included in $x_{i t}$ are the typical demographic variables such as number of children in each age group, partner's age and education, and housing tenure. Following the majority of such models, the wage rate is assumed to be a function of, and replaced by, variables 
indicating human capital stock such as: labour market experience and its square, education, indicators for birth place and languages other than English, and so on. ${ }^{6}$

To identify the job loss effect, we also estimated reduced-form models for probabilities of increases in labour market activities - of increase in hours worked and of preferring to increase hours. The specifications are similar to those in Equation (2), except for the left-hand-side probabilities, which refer to the probabilities of an increase in hours worked, and of preferring to increase hours. Loosely speaking, the coefficients of job loss can then be seen as estimated by difference-in-difference methods.

\section{Estimation Results}

The estimated coefficients of the partners' job loss in the equations for labour force participation, full-time employment, increase in hours worked and preference to work more hours are presented in Table 4. The coefficients are explained as the ceteris paribus marginal effects of the corresponding variable on the explained probability. The estimates are based upon the fixed effects linear probability model.

Looking first at the coefficients for the current period job loss $\left(\eta_{0}\right)$, Table 4 shows that the added worker effect on participation is not significant - the job loss effect in the participation equation is positive but not significant. However, the coefficients for all three other measures are all significantly positive (at least at the 10 per cent level). It seems that, compared with those women whose partners had not experienced job loss, the women with partners who had lost jobs in the current period were 2.8 percentage points more likely to be full-time employed, 4.3 percentage points more likely to be working more hours, and 4.5 percentage points more likely to prefer to work more hours. This implies that the women's increased labour supply comes from increases in hours worked, especially from increases in full time employment, but not from increases in participation. This may reflect constraints in the labour market — it may be easier to increase working hours than to enter the labour market.

\footnotetext{
${ }^{6}$ In the linear fixed effects model, however, the time-invariant variables will drop out because of the differencing.
} 
Turning to the coefficients relating to job loss in the previous but not current period $\left(\eta_{-1}\right)$, all but one are insignificant, with the significant one being in the equation for the preference to increase hours of work. The probability of wishing to increase hours worked is 4.9 percentage points more for women with partners with job loss experiences in the previous period, compared to women whose partners did not experience job loss. This suggests that, in the event of the male partner's job loss, those females who are able to respond do so reasonably quickly though, after one year, others would still like to increase their working hours but were possibly not able to do so at least in the short run (as reflected by the insignificant parameter in the other equations). The finding indicates that the AddWE is persistent. This may also reflect the rigidity in the labour market and constraints on the individuals' ability to increase labour market activity.

The third column in Table 4 covers the effect of job loss in the future period (the 12 months after interview). Unlike Stephens (2002), the anticipated (future) job loss effect is not found to be significant in any of the four equations, although all but one are positive. This may be due to the small sample size problem and may be because of the way the variables are defined. Some of the future job loss effects are already picked up in the previous and current job loss coefficients and only a few individuals are observed to experience job loss in the future only.

Table 4. Coefficient estimates of male partners' job loss (in percentage points)

\begin{tabular}{|c|c|c|c|}
\hline \multirow[b]{2}{*}{$\begin{array}{l}\text { Labour market activities } \\
\text { of married women }\end{array}$} & \multicolumn{3}{|c|}{ "Coefficients of partner's job loss experiences } \\
\hline & $\begin{array}{l}\eta_{-1} \text { (The effect of the } \\
\text { previous but not current period } \\
\text { event) }\end{array}$ & $\begin{array}{l}\eta_{0} \text { ( The cumulative } \\
\text { effect of the current } \\
\text { period event) }\end{array}$ & $\begin{array}{l}\eta_{-1} \text { (The effect of the } \\
\text { future period event only) }\end{array}$ \\
\hline Participation & 0.7 & 2.1 & -1.1 \\
\hline Full-time employment & -0.8 & $2.8 * *$ & 1.7 \\
\hline hours-worked increased & 2.2 & $4.3^{*}$ & 3.1 \\
\hline Prefer to increase hours & $4.9 * *$ & $4.5 * *$ & 0.4 \\
\hline
\end{tabular}

Although OLS and random effects models are likely to be inconsistent estimators, the estimated job loss effects using these alternative models are presented for comparison in Table B of the Appendix. What can be picked up there is that the job loss effects, 
especially for the full time employment equation and for the preference to increase hours equation, are quite robust to the model specifications.

In Table $\mathrm{C}$ of the Appendix, coefficient estimates of the other variables are presented for the fixed effects model. The coefficients of both the participation equation and the full time employment equation are largely consistent with the labour supply literature: for example, a greater number of young children tends to discourage women from paid work. For the two increase-in-hours equations, it is worth noting that the variables other than the job loss variables did not have much explanatory power. This result is expected and confirms the view that the increases in hours worked are stemming from the job loss of partners.

\section{The discouraged worker effect}

The discouraged worker effect is analysed by estimating a reduced form Probit model of labour force participation for all married women and a model of labour force participation in the subsequent year for the job-seekers. Included in the models are the state-level unemployment rates, together with the demographic variables usually found in such models. For the job-seekers, the self-assessed job-finding probability is also included. ${ }^{7}$ The full list of the explanatory variables and the estimated marginal effects for the two models are presented in Table D in the Appendix. The marginal effects are calculated at the sample mean and are interpreted as the change in the participation probability for a unit change in the corresponding explanatory variable, ceteris paribus. For example, for the job-seekers, the value of 0.004 corresponding to the self-assessed job-finding probability means that every percentage point increase in the self-assessed job-finding probability would increase the likelihood of subsequent participation by 0.4 percentage points. In other words, with everything else being the same, the more pessimistic is the job-seeker, the less likely is she to be participating in the labour force a year later. For this group of job-seekers, the aggregate unemployment rate appears to have insignificant impact on their labour force participation. However, the marginal effect of the unemployment rate on contemporary labour force participation for all

\footnotetext{
${ }^{7}$ The participation equation for all married women is estimated without the self-assessed job-finding probability because the information is missing for those who are not in the labour force.
} 
married women is negatively significant. Its magnitude is found to be -0.012 which means that, for every percentage point increase in the unemployment rate, the likelihood of labour force participation of the averaged married women drops by 1.2 percentage points.The general findings for the other variables are consistent with the literature. For example, labour force participation increases with education level, decreases with the number of young children, and so on.

\section{Conclusions}

Using seven waves of data from the HILDA Survey, this paper has examined the added worker effect by studying the labour supply responses by married women to their partners' job losses. As in Stephens (2002), we argue that the unemployment status of the partners is not appropriate for studying the added worker effect. Instead, we investigate the added worker effect in the context of the family life-cycle labour supply model with a direct focus on partners’ recent job losses.

Job loss of the family members brings income shocks to the families. Economic theories predict that, in the cases of such adverse shocks, other family members would increase their labour supply to compensate for the income loss. Our empirical analysis confirmed the predictions and found a significant added worker effect for Australian women in terms of increases in full-time employment and in terms of increased working hours.

The results show that the added worker effect mainly comes from increases in working hours by existing workers (especially in terms of full-time employment) and it implies that it is harder for these women to increase their labour market activities by entering the labour market than by increasing working hours when already working. Compared to their counterparts whose partners have not experienced a recent job loss and are not about to lose their job, the likelihood of labour force participation of women with partners who have experienced recent job losses is about 2.8 percentage points higher, they are 4.3 percentage points more likely to have increased their hours worked, and are 4.5 percentage points more likely to prefer to increase hours. The results also show that, one year after the partners' job loss, the women are more likely to prefer to work longer hours than those women whose partners did not have recent job loss experiences. This 
indicates a persistent effect, one that is also predicted by the theory. The result also suggests rigidity in the labour market and a limited ability for these women to increase their labour market activities. It is important to note that the AddWE is only one side of the coin. To get a full account of increasing unemployment on women's labour supply, the discouraged worker effect also has to be taken into account.

By estimating reduced-form labour force participation equations separately for all married women and for job-seekers only, we find that for every percentage point increase in the unemployment rate, the married women's labour force participation rate would drop by 1.2 percentage points. We also find that the job-seekers are reasonably realistic about their chances of getting a job, and that the job-seekers' subsequent participation is significantly affected by this self assessment, with the likelihood of participation dropping by 0.4 percentage points for every one percentage point drop in the self-assessed job-finding probability. The results support the expectation that, in an economic downturn, it is much less likely for either the job-losers to find jobs again or for their partners to be able to compensate the lost income by increasing their working hours. With such a large discouraged worker effect, the financial impact of job loss would be expected to be much larger than in the period of strong economic conditions that has provided the basis for this analysis. It would be interesting to test these expectations by re-examining the issue when data are available relating to the recent economic downturn. 


\section{References}

ABS. 2001, 2004, and 2008. Labour force, Australia, Dec 2001, Dec 2004, and Dec 2008, Australian Bureau of Statistics, www.abs.gov.au.

Ashenfelter, O. 1980. "Unemployment as Disequilibrium in a Model of Aggregate Labor Supply." Econometrica, 48 (3), 547-64.

Bowen, W. and T. Finegan. 1968. The Economics of Labor Force Participation, Princeton, Princeton University Press.

Bradbury B. 1995. “Added, Subtracted or Just Different: Why Do the Wives of Unemployed Men Have Such Low Employment Rates?”, Australian Bulletin of Labour , 21(1):48-70.

Gruber, J. and J. Cullen. 1996. "Spousal Labor Supply as Insurance: Does Unemployment Insurance Crowd Out the Added Worker Effect?”, National Bureau of Economic Research Working Paper No. 5608.

Heckman, J. and T. MaCurdy. 1982. "Corrifendum on a Life Cycle Model of Female Labour Supply”, Review of Economic Studies, 49 (4), 659-660

Killingsworth, M., and J. Heckman. 1986. "Female Labor Supply: A Survey," in Handbook of Labor Economics, edited by Ashenfelter, O. and R. Layard. New York: Elsevier Science Publishing Company, Inc., 103-204.

Layard, R. M. Barton, and A. Zabalza. 1980. “Married Women’s Participation and Hours”, Economica, 47 (185), 51-72.

Lenten, L. 2000. “The Profile of Labour force Discouragement in Australia”, Australian Journal of Labour Economics, 4 (1), 3-17.

Lundberg, S. 1985. "The Added Worker Effect", Journal of Labor Economics, 3 (1), 1137. 
MaCurdy, T. 1985. "Interpreting Empirical Models of Labor Supply in an Intertemporal Framework with uncertainty”, Longitudinal Analysis of Labor Market Data, eds. Heckman, J. and B. Singer. Cambridge: Cambridge University Press.

Maloney, T. 1987. "Employment Constraints and the Labour Supply of Married Women: A Reexamination of the Added Worker Effect”, Journal of Human Resources, 22 (1), 5161.

— . 1991. "Unobseerved Variables and the Elusive Added Worker Effect", Economica, 58 (230), 173-187.

Mincer, J. 1962. "Labor Force Participation of Married Women: A Study of Labor Supply," in Aspects of Labor Economics, edited by H. G. Lewis. Princeton N.J.: National Bureau of Economic Research, Princeton University Press, 63-97.

— . 1966. "Labor-Force Participation and Unemployment: A Review of Recent Evidence," in Prosperity and Unemployment, edited by R. A. Gordon. New York: Wiley, 73-112.

Morissette, R. and Y. Ostrovsky. 2008. "How do Families and Unattached Individuals Respond to Layoffs? Evidence from Canada”, Research Paper, Statistics Canada, Ottawa, Canada.

Pencavel, J. "Unemployment and the Labor Supply Effects of the Seattle-Denver Income Maintenance Experiments." Research in Labor Economics, 5, 1-31.

Rosen, S. 1992. "Distinguished Fellow: Mincering Labor Economics." Journal of Economic Perspectives, 6 (2), 157-70.

Spletzer, J. 1997. “Reexaming the Added Worker Effect”, Economic Inquiry ,35 (2), 417427.

Stephens, M. 2002. "Worker Displacement and the Added Worker Effect", Journal of Labor Economics, 20 (3), 504-537. 
Topel, R. 1990. "Specific Capital and unemployment: Measuring the Costs and Consequences of Job Loss”, Carnegie-Rochester Conference Series on Public Policy, 33 (2), 191-214.

Woytinsky, W. 1940. "Additional workers on the labor market in depressions: a reply to Mr. Humprey”, Journal of Political Economy, 48 (5), 735-40.

\section{Appendix}

\section{Table A. Summary Statistics}

\begin{tabular}{|c|c|c|}
\hline Variable definition & Mean & Standard Deviation \\
\hline Age & 39.7 & 9.2 \\
\hline Speaks languages other than English (\%) & 10.9 & \\
\hline Born in Australia (\%) & 58.9 & \\
\hline Born in main English speaking countries (\%) & 28.9 & \\
\hline Born in other countries (\%) & 12.2 & \\
\hline Received higher education (\%) & 27.5 & \\
\hline Received vocational education (\%) & 25.3 & \\
\hline Finished Year $12(\%)$ & 15.6 & \\
\hline Did not finish Year 12 (\%) & 31.6 & \\
\hline No. of children between 0 and 5 & 0.43 & 0.7 \\
\hline No. of children between 6 and 12 & 0.51 & 0.8 \\
\hline No. of children between 13 and 15 & 0.22 & 0.5 \\
\hline No. of children between 16 and 17 & 0.12 & 0.3 \\
\hline No. of children between 18 and 20 & 0.11 & 0.3 \\
\hline Hours increased $(\%)$ & 27.1 & \\
\hline Wish to increase hours & 15.3 & \\
\hline Participation rate (\%) & 74.3 & \\
\hline Employed (\%) & 72.1 & \\
\hline Working full-time (\%) & 37.6 & \\
\hline Working part-time (\%) & 36.5 & \\
\hline Unemployed (\%) & 2.2 & \\
\hline Non-participation (\%) & 25.7 & \\
\hline Partner's age & 41.9 & 9.5 \\
\hline Partner received higher education (\%) & 25.8 & \\
\hline Partner received vocational education (\%) & 41.9 & \\
\hline Partner finished Year $12(\%)$ & 10.7 & \\
\hline Partner did not finish Year $12(\%)$ & 22.0 & \\
\hline Partner lost job involuntarily during the last 12 months (\%) & 3.1 & \\
\hline Partner lost job involuntarily a year ago but not during the last 12 months (\%) & 2.2 & \\
\hline Partner is employed (\%) & 90.5 & \\
\hline Partner is not working (\%) & 9.5 & \\
\hline Unemployed (\%) & 2.0 & \\
\hline Renting the house (\%) & 20.3 & \\
\hline Paying off the mortgage (\%) & 51.4 & \\
\hline State level unemployment rate ${ }^{8}$ & 5.7 & 1.2 \\
\hline Obs. (individuals and waves) & 18,448 & \\
\hline
\end{tabular}

Source: Authors' calculation using HILDA, waves 1-7.

\footnotetext{
${ }^{8}$ Obtained from ABS (2001, 2004, and 2008)
} 
Table B. Coefficient estimates of partners' job loss from alternative models

\begin{tabular}{|c|c|c|c|}
\hline \multirow[b]{2}{*}{ Equation } & \multicolumn{3}{|c|}{ "Coef. of partner’s job loss experiences (\%-points) } \\
\hline & $\begin{array}{l}\text { The previous but not current } \\
\text { period }\left(\eta_{-1}\right)\end{array}$ & Current period ( $\left.\eta_{0}\right)$ & $\begin{array}{l}\text { The future period only } \\
\left(\eta_{-1}\right)\end{array}$ \\
\hline \multicolumn{4}{|c|}{ OLS } \\
\hline Participation & -1.6 & 0.6 & -1.2 \\
\hline Full-time employment & 1.4 & $5.6 * *$ & $3.2 *$ \\
\hline hours-worked increased & 3.0 & 1.9 & 3.0 \\
\hline Prefer to increase hours & $5.0 * *$ & $4.4 * *$ & 1.8 \\
\hline \multicolumn{4}{|c|}{ Random effect Probit model } \\
\hline Participation & 0.3 & 1.5 & -1.2 \\
\hline Full-time employment & -2.1 & $5.7 * *$ & 3.6 \\
\hline hours-worked increased & 3.0 & 1.9 & $3.2^{*}$ \\
\hline Prefer to increase hours & $3.7^{* *}$ & $4.1^{* *}$ & 0.9 \\
\hline \multicolumn{4}{|c|}{ Linear random effect model } \\
\hline Participation & 0.1 & 1.5 & -1.1 \\
\hline Full-time employment & -0.2 & $3.5^{* *}$ & 1.9 \\
\hline hours-worked increased & 3.0 & 1.9 & 3.0 \\
\hline Prefer to increase hours & $5.0 * *$ & $4.4^{* *}$ & 1.1 \\
\hline
\end{tabular}

* Significant at 10\% level; ** significant at 5\% level. The reference group comprises the women with partners having no job loss experiences in any of the three periods.

Source: Authors' calculation using HILDA, waves 1-7.

Table C. Estimated coefficients of demographic variables in the linear fixed effect model

Variables

No. of children $0-5$

No. of children 6-12

No. of children 13-15

No. of children $16-27$

No. of children $18-20$

partner's age

experience

experience-sq

renting home

paying mortgage

constant

Obs.

*Significant at $10 \%$ level; ** significant at $5 \%$ level

Source: Authors' calculation using HILDA, waves 1-7.
Equations

\begin{tabular}{llll}
$\begin{array}{l}\text { Hours } \\
\text { increased }\end{array}$ & $\begin{array}{l}\text { Prefer to increase } \\
\text { hours }\end{array}$ & Participation & $\begin{array}{l}\text { Full-time } \\
\text { employment }\end{array}$ \\
\hline-0.011 & 0.005 & $-0.137^{* *}$ & $-0.204^{* *}$ \\
0.010 & $0.018^{* *}$ & $-0.021^{* *}$ & $-0.105^{* *}$ \\
-0.001 & 0.005 & -0.009 & $-0.061^{* *}$ \\
-0.012 & 0.007 & 0.011 & $-0.033^{* *}$ \\
0.003 & -0.001 & -0.001 & $-0.022^{* *}$ \\
$0.023^{* *}$ & 0.003 & -0.004 & $-0.010^{* *}$ \\
-0.065 & 0.084 & $0.954^{* *}$ & $0.769^{* *}$ \\
-0.001 & 0.001 & $0.010^{* *}$ & $0.008^{* *}$ \\
-0.005 & -0.004 & 0.014 & $0.034^{* *}$ \\
0.022 & 0.004 & $0.023^{* *}$ & $0.023^{* *}$ \\
$-0.678^{* *}$ & -0.079 & $0.743^{* *}$ & $0.789^{* *}$ \\
& & 18,448 & \\
\hline
\end{tabular}


Table D. Estimated marginal effects on participation of married women (based upon Probit models)

\begin{tabular}{|c|c|c|c|c|}
\hline \multirow[b]{2}{*}{ Variables } & \multicolumn{2}{|c|}{ Job-seekers at $t$-1 } & \multicolumn{2}{|c|}{ All } \\
\hline & Effect & $t$-value & Effect & $t$-value \\
\hline Prob. of getting a job at $t-1$ & $0.004 * *$ & 4.68 & - & \\
\hline State unemployment rate & 0.006 & 0.25 & $-0.012 * *$ & -3.87 \\
\hline No. of children 0-5 & $-0.067^{*}$ & -1.69 & $-0.148 * *$ & -31.8 \\
\hline No. of children 6-12 & -0.032 & -0.91 & -0.006 & -1.56 \\
\hline No. of children $13-15$ & -0.043 & -0.71 & 0.011 & 1.54 \\
\hline No. of children 16-27 & 0.060 & 0.72 & $0.049 * *$ & 4.61 \\
\hline No. of children $18-20$ & -0.022 & -0.25 & $0.042 * *$ & 4.00 \\
\hline partner's age & -0.004 & -0.90 & $-0.014^{* *}$ & -28.92 \\
\hline Experience/100 & 0.691 & 0.69 & $1.879 * *$ & 39.47 \\
\hline renting home & 0.095 & 1.31 & -0.009 & -0.84 \\
\hline paying mortgage & 0.089 & 1.34 & $0.052 * *$ & 6.42 \\
\hline Birthplace: Eng-speaking & -0.055 & -0.90 & -0.002 & -0.25 \\
\hline Birthplace: non-Eng-speaking & -0.002 & -0.03 & $-0.047 * *$ & -4.23 \\
\hline Received higher education & $0.166^{* *}$ & 2.31 & $0.134 * *$ & 15.72 \\
\hline Received vocational education & $0.160 * *$ & 2.26 & $0.018 *$ & 1.83 \\
\hline Not finishing Year 12 & 0.039 & 0.50 & $-0.090 * *$ & -8.57 \\
\hline Partner lost job involuntarily & $0.180^{*}$ & 1.62 & 0.013 & 0.74 \\
\hline Obs & \multicolumn{2}{|c|}{396} & \multicolumn{2}{|c|}{18,448} \\
\hline
\end{tabular}

* Significant at $10 \%$ level; ** significant at 5\% level.

Source: Authors' calculation using HILDA, waves 1-7. 